\title{
Malek Bennabi's concept and interdisciplinary approach to civilisation
}

\section{Badrane Benlahcene}

Faculty of Arts,

King Faisal University,

P.O. Box 1759, Ahsaa 31982, Saudi Arabia

Fax: 0966/3/5812978

E-mail: drbadran68@yahoo.com

E-mail: drbadran68@hotmail.com

\begin{abstract}
This article examines Malek Bennabi's concept of civilisation and its equation. It undertakes a conceptual approach to Bennabi's analysis of the term 'civilisation' and his efforts in conceptualising civilisation and analysing its fundamental components and the appropriate approach to it as a socio-historical and cultural phenomenon. The article will answer this question by looking at the various conceptualisations put forth by Bennabi about civilisation, its structural ingredients, and the interdisciplinary approach to civilisation as developed by Bennabi to tackle the various aspects of civilisation as multidimensional phenomenon.
\end{abstract}

Keywords: Bennabi; civilisation; approach; culture; interdisciplinary; Muslim; colonisability; religion; development; ingredients.

Reference to this paper should be made as follows: Benlahcene, B. (2011) 'Malek Bennabi's concept and interdisciplinary approach to civilisation', Int. J. Arab Culture, Management and Sustainable Development, Vol. 2, No. 1, pp.55-71.

Biographical notes: Badrane Benlahcene is an Associate Professor of Islamic Philosophy and Philosophy of History at the Department of Philosophy, The Faculty of Literatures and Humanities, Batna University, Algeria.

\section{Introduction: contextualising Bennabi}

Since the publication of Samuel Huntington's (1993) now famous article 'The clash of civilizations', the concern about civilisation has been reintroduced into the debate on the world order in intellectual circles. It has enhanced the previous efforts of philosophers of history and social scientists to establish civilisation studies as a distinctive field of research. It paid attention to the importance of the study of civilisations and their importance for an understanding of global change. Furthermore, the end of the so-called Cold War and the collapse of the Soviet Union brought to the debate the issue of civilisation studies and related questions even though the very category of 'civilisation' and 'civilisations' had been avoided by most intellectual and political circles until recently. 
In this context, many researchers and scholars called for the review and reexamination of the works of those leading civilisationists (Sanderson, 1995) among the historians, sociologists, anthropologists, and philosophers who explored, at length, issues such as the causes, emergence, rise, interactions, achievements, decline, and fall of civilisations. The list of those leading civilisationists includes among others, Ibn Khalduun (1332-1406), Comte (1798-1857), Spengler (1880-1936), Weber (1864-1920), Durkheim (1858-1917), Toynbee (1889-1975), Sorokin (1889-1968), Kroeber (1876-1960), Braudel (1902-1985), etc. (Huntington, 1996).

In the Muslim World, since the early 20th century there were efforts to view history from a civilisational perspective. Among the thinkers and leaders of those efforts, Malek Bennabi (1905-1973) a scholar of profound ideas, and leading Muslim Algerian intellectual.

Bennabi was also one of the few original thinkers who have succeeded in making remarkably systematic contributions. He set out to search for universal laws and fundamental principles that govern human societies and civilisations, and determine their destiny in history.

From the 1940s until his death in 1973, he wrote numerous books and articles providing penetrating insights into the philosophy of history, sociology, social and historical change and pressing cultural and civilisational issues, as well as different cultural traditions that have engaged prominent thinkers of all ages.

However, the central theme of Bennabi's thought was the study of civilisation in general, and the attempt to provide solutions to the state of Muslim civilisation in particular. In other words, Muslim civilisation was the starting point for Bennabi to study civilisation and to theorise about this issue.

Since his early years, Bennabi was drawn to the stagnation in which Muslims dwelled. Therefore, he was involved in many intellectual and activist movements in efforts to reactivate the civilising process in the Muslim world. However, the many attempts made in various quarters seemed fruitless to Bennabi because of the lack of clear vision and a methodology to approach the matter.

As asserted by many, Bennabi directed his efforts to reactivate the dynamism of the Muslim civilisation by developing his approach to the study of civilisation in general and Muslim civilisation, in particular. While many activists and intellectuals tended to resolve the present dilemma of backwardness of the Muslim world in terms of economics, politics or ideology, he emphasised the role of ideas as the catalyst behind the growth of civilisation. Civilisation, Bennabi maintains, is not an accumulation, rather, a construction and an architecture (Ibrahim, 1991).

Drawing upon a deep understanding of Islam, a sound assimilation and insight of the social sciences, and a proper grasp of the dynamics of human society and history, Bennabi adopted an etiological approach that allowed him to gain considerable knowledge into the performance of human societies and the workings and dynamics of culture and civilisation as seen from a universal perspective (Bariun, 1993).

He directed all his efforts to resolve societal problems within the framework of civilisation. In other words, he considered civilisation as the intelligible unit with which to study socio-historical phenomena. In this regard, he viewed civilisation as the core of any study of human conditions in their short term or long term scale. He said: 


\begin{abstract}
"The problem of every people, in its essence, is that of its civilization. And it is not possible for any people to comprehend and resolve its problem, if it does not elevate its thought and capacities to the level of the great human affairs and speculate deeply in order to understand the factors which construct and deconstruct the civilizations." (Bennabi, 1981)
\end{abstract}

The main question is: What is Bennabi's concept of civilisation and its equation? This paper tries to answer this question by looking at the various conceptualisations put forth by Bennabi about civilisation, its ingredients, and the interdisciplinary approach to civilisation as developed by Bennabi to tackle the various aspects of civilisation as multidimensional phenomenon.

This article argues also that any reader who becomes acquainted with Bennabi's treatise on civilisation will find that the ideas and the vocabulary of his thought are a mixture of and a result of the examination of the works of many leading thinkers and may not be totally new if viewed from a partial perspective. This does not mean, however, that his ideas are drawn from existing sources and put side by side as heterogeneous elements. Bennabi's thought is, indeed, an organised totality, or a system into which all concepts, terms and ideas, whatever their origin, have been integrated with an entirely systematic interpretation.

Compared to other thinkers and civilisationists, Bennabi's approach to civilisation still needs to be deeply analysed and understood. It is still not fully uncovered and implemented. He has especially developed his approach to civilisation to present a diagnosis of the phenomena that dominate the contemporary Muslim world and explain their origins, and how to get rid of them as phenomena of backwardness (Talbi, 1991). The latter suggests that Bennabi's approach to the different issues related to the study of civilisation and its course in history has great importance in the intellectual milieu for the diagnosis of the Muslim civilisational crisis.

As mentioned previously, although Bennabi's work has been available in French and Arabic since the late $1950 \mathrm{~s}$, his ideas or methodological approach to the study of the various problems of the Muslim civilisation seldom received serious scholarly attention before the 1980s (Arif, 1994). Rather, in many instances he was misunderstood and even sometimes misrepresented by different and conflicting ideological quarters (Bennabi, 1998).

Some of those who are interested in his thought consider him a writer, thinker, and probably the first social philosopher and social scientist the Muslim world has seen since the time of Ibn Khalduun (Jad'an, 1988; Rachid, 1978). Others consider him a philosopher-visionary for the entire Ummah whose concern about the decadence of the Muslim civilisation led him to analyse the causes of the decay and to provide solutions.

In the same context, Mesawi (1991) and Hassan (1991) asserted that the significance of Bennabi's thought derives from his scientific training combined with a historical, sociological, and philosophical outlook which enabled him to fathom the depths of European civilisation and gain a deep understanding of its culture, as well as from his original thinking and analysis of the Ummah's strengths and weaknesses. Therefore, Hassan asserted that Bennabi's scope ranged across social, political, economic, moral and theological speculations (Hassan, 1991).

The above mentioned arguments by the scholars of Bennabi's thought suggest a conceptual analysis of his very basic ideas concerning civilisation and its related fundamental ingredients and approach. 


\section{The starting point of Bennabi's approach}

In the 1930s, Bennabi realised that the crisis of the Muslim world could not be diagnosed by means of a superficial analysis. Thus, while he acknowledged their efforts he also criticised the two trends in the modern Muslim world, the reformist and modernist, for not determining the real causes of the crisis and for not going beyond its symptoms. In those efforts, according to Bennabi, "there was no methodological analysis of the crisis, a diagnostic and pathological study of the Muslim society" [Bennabi, (1981), p.40]. He also criticised those who put the blame on external factors but ignored internal ones (ibid, p.31, p.40).

He asserts that the efforts to bring about a renaissance in the Muslim world did not develop a systematic approach to the crisis in order to provide solutions for the Muslim society. In this regard, he undertook a critical review of the various trends and ideas in the modern Muslim world, not only to understand what was at fault, but also to develop his own ideas and suggestions for regeneration [Bariun, (1993), p.147].

Furthermore, he criticised those who related the crisis to the lack of means and instruments. The problem was rooted in the Muslim culture of the post - al-Muwahhid era. It was in their minds, souls, and behaviour. That is why Bennabi (1981, p.113) said, "The matter is not a matter of means and instruments. Rather, it is matter of methods and ideas".

To understand and tackle the crisis which did not start with the colonial era, Bennabi was of the opinion that it is important to take into consideration the historical process of that crisis that paved the way for the spirit of colonisability (ibid, Qaḍa $\bar{a} \bar{a}$ Kubrā, pp.52-53) in order to cope with its essence rather than its manifestations, which did not start with the colonial era but with the post - al-Muwahid era that paved the way for the spirit of colonisability (ibid, Qa da āyā Kubrā, pp.52-53).

Colonisation is not the main reason for the present situation in the Muslim world, but it is one of the many secondary factors. The primary factor is colonisability, that is, our vulnerability to be colonised (ibid, Shurūt al-Nahzah, p.31, pp.152-153). In other words, the present state of the Muslim world requires a deeper analysis which goes beyond partial appearances and symptoms and undertakes a systematic examination of the historical process of backwardness in order to find its starting point and its pivotal factors. It needs to examine the status of humans and their culture so much so that any change that does not take this factor in consideration will not be important.

According to Bennabi, it is an issue of a comprehensive theory for the renaissance in the Muslim world. Therefore, he set out to discover the roots of the crisis and proposed a systematic orientation towards the efforts and activities of that movement, which should be based on the diagnosis of the different stages of the Muslim society throughout history (ibid, Fikrat Commonwealth Islāmī, p.26).

The next step was to look for a central theme or unit that could be used to tackle the various manifestations of the crisis.

The central unit, which includes all other partial diagnoses, was absent in the efforts of the renaissance, because the movement lacks methodological and scientific thinking [Bariun, (1993), p.150]. Therefore, the Muslim world is suffering from various crises which Bennabi summed up in one expression: 'civilisational crisis' (ibid, Dawr al-Muslim Wa Risālatuh F̄̄̄ al-Thuluth al-Akhīr Min al-Qarn al-’Ishrīn, p.46).

The problem of every people, in its essence, is that of its civilisation. And it is not possible for any people to comprehend and resolve its problem if it does not elevate its 
thought and capacities to the level of the great human events and speculate deeply in order to understand the factors which construct and deconstruct civilisations (ibid, Shurūt al-Nahzah, p.19).

The political, economic, social and educational crises in the Muslim society are mere manifestations of the civilisational crisis which is the real and core crisis. Accordingly, any solution given to alleviate those symptoms will not change the situation of the Muslim and their society. On the contrary, it will exacerbate it, and create an even worse situation (ibid, p.41).

The previous paragraph quoted from The Conditions of Renaissance also suggests a central unit that integrates the critical aspects of the present state of Muslim civilisation. This unit is 'civilisation,' or as Toynbee called it 'the intelligible unit of analysis' [Toynbee, (1974), pp.1-11].

The study needs an integrated approach which facilitates a comprehensive understanding of such a phenomenon (ibid, p.61). Bennabi called for the use of an interdisciplinary approach which derives its general rules from various sciences such as history, sociology, psychology and metaphysics [ibid, Mīlād Mujtama', p.75; Bennabi, (1998), p.89].

Scholars of Bennabi also emphasise and agree on Bennabi's field of research and approach. They consider that the study of civilisation is his internal field of study and focal concern. They also agree that he presents a different approach with respect to his terms, definitions, concepts, the units of analysis, the scope of the analysis and the perspective he adopted (Bariun, 1993; Mesawi, 1998; Ubādah, 1984; Ukāshah, 1986; Al-Saḥmarānī, 1986; Al-Khatīb, 1986; Al-Mīlād, 1992).

Every scholar with a new message to convey introduces his or her own terms, concepts, and definitions, and Bennabi is no exception. Although he borrows from various paradigms, schools of thought, approaches, and thinkers, he was novel and original in his synthesis of various ideas, and in putting forth a new system of tackling the issues of civilisation (Gassum, 1994).

\section{Bennabi's concept of civilisation}

\subsection{Definition of civilisation}

Bennabi's definitions of civilisation are many, they come from different perspectives, and are a multidimensional phenomenon. Therefore, in order to ascertain Bennabi's understanding of the meaning of civilisation, I classified the definitions into six categories:

Civilisation can be defined as being the sum total of the moral as well as material conditions which allow a given society to provide each one of its members with all the social guarantees necessary for his development (Bennabi, 1994).

The term civilisation is used to indicate the balance between the moral and the material aspects in human life. Bennabi did not determine civilisation by moral and spiritual conditions alone, or by material conditions alone, as generally defined by anthropologists. Rather, he was aware of the importance of the sum total of all conditions.

Civilisation is a "self-force that refines the primitive features within the individual and societal context" (ibid, Qaḍ $\bar{a} y \bar{a}$ Kubrā, p.91). It is but "the ability to carry out a 
specific mission and accomplish a distinct function" (ibid, The Problem of Ideas, p.26). It is a kind of psychological and mental force that organises human capacity and human vital energy to respond to the needs of development and progress. Civilisation becomes a self-character and a self-potency that helps humans control behaviours and energy, and directs it towards the benefit of society.

Bennabi was of the view that civilisation is, in its essence, an idea and a project for systematic work. It activates social capacities in order to face the crucial problems of a society (Bennabi, 1986). In other words, civilisation is

\begin{abstract}
"[the] result of a living dynamic idea, which mobilises a pre-civilised society to enter history and construct a system of ideas according to its archetypes. So the society thereafter, develops an authentic cultural milieu, which in return, controls all the characteristics which distinguish that society from other cultures and civilisations." (ibid, The Problem of Ideas, p.25)
\end{abstract}

Bennabi defines civilisation essentially as

"The total result of the moral and material conditions which grant a given society the possibility to offer each one of its members, in every stage of his existence from childhood till afterlife, with necessary social assistance requested for his growth in this stage or in the other." (ibid, Qad̄āya Kubrāa, p.43)

Bennabi denotes that civilisation is a social force that plays an important role in the development of the individual and society as well. It is a sum total of the moral and material conditions. The individual does not provide those aspects himself; society offers them, generates civilisation, and helps the individual to play his role in history as a civilisational force. Bennabi gives precedence to society over the human, in his definition. For him, humans as individuals cannot construct a civilisation, but it is the society or the group that can initiate the civilising process and take the first step toward its historical progress. Society gives the real meaning for human activities in the realm of history. It constitutes the progressive milieu that helps the individual to carry out his responsibilities in the form of a mission and a function.

Consequently, in Bennabi's conception, society is the core force in any civilising process. It allows the individual to possess the guarantees he needs in his progress and development. The individual is just as important, and contributes to the development of his society as an integrated member in the social movement.

His role depends on the level of sociability and societal interaction that limits his position and role in the entire movement of human development. The latter is the role of civilisation from the functional perspective. It builds a dialectic relationship between society and the individual, and links the integrated individual to its society as part of one single unit that undergoes the civilising process towards a state of stability, growth, and prosperity.

Bennabi asserts that moral and material factors are crucial in creating balance and liveliness in human society on the one hand, and generating solidarity and unity among the members of society, on the other. The sum total of moral and material conditions provides the social services for the members of society. That is why Bennabi does not concentrate only on the products and objects of a civilisation, but on the moral aspects that come first in the civilising values. Therefore, if civilisation does not provide these two kinds of assistance, particularly the moral one, it will not be able to create the civilising milieu. 
Bennabi defines civilisation, this time, by focusing on the structure and the social essence of civilisation. Thus, civilisation means that the human being learns how to live within a group and perceives at the same time the essential importance of the network of social relations in organising human life in order to perform its historical function and responsibilities (ibid, Mīlād Mujtama', p.88).

This definition reflects the importance of the network of social relations among the members of society. Civilisation helps to formulate the network of social relations that makes social interaction and education among the members of society possible and beneficial.

Bennabi gives another definition which emphasises the socio-intellectual dimension of civilisation.

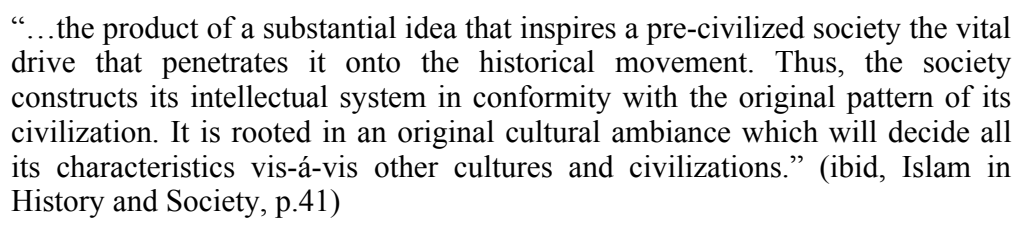

Ideas are the significant social force that gives the society its intellectual characteristics, cultural originality, and social vitality. Indeed, ideas are the prime force that drives society to enter into history in order to accomplish its mission and to carry out its responsibilities in a given historical moment.

Bennabi's different approaches formulate his unique concept of civilisation as the intelligible unit with which to study the problem of the backwardness in the Muslim world.

From these various definitions the integrative approach stands out. Civilisation seems to be like a multidimensional concept that enables us to reconcile its integral parts in order to constitute its entire dynamic structure. The latter led Bennabi to call for and apply an interdisciplinary approach to study the complex phenomenon of civilisation. In the next section, a discussion of Bennabi's interdisciplinary approach may help in the more systematic understanding of his concept of civilisation.

\subsection{The interdisciplinary approach to civilisation}

Bennabi drew attention to the importance of an interdisciplinary approach to study civilisation. The definitions presented previously suggest an integrative way to do it objectively. Many disciplines are required to analyse civilisation as a social phenomenon, and Bennabi was aware of its multidimensionality. For that reason, he examined it from different angles, using various sciences, and taking into consideration the integrative character of the dimensions of civilisation as one set.

Bennabi asserted that civilisation is a social phenomenon not a physical one. Therefore, when studying it and its historical movement, one should be aware of the complexity of social phenomena which is difficult in nature because of certain weaknesses in the methods of social analysis.

He says

"unlike the natural sciences, human sciences have not yet achieved such a level of maturity as to provide universally applicable definitions for their concepts and terms" [Bennabi, (1998), p.5]. The result is that "the rule in sociology is not like that in precise science, a strict limit between truth and falsehood, right 
and wrong, but it is just general guidance by which we can avoid the outrageous mistakes." (ibid, Shurūt al-Nahzah, p.42)

In other words, dealing with the social phenomena is more complicated than dealing with mathematics or natural phenomena. This is because there is an original difference in their nature and field. Approaching civilisation as a social phenomenon requires a correct understanding of its nature and scope.

For instance, social scientists face certain difficulties in determining the moment of birth of one civilisation and the decline of another. They cannot explain precisely the direct and indirect reasons for the development of any civilisation. In fact, Bennabi asserts that the methods for studying it are unable to draw "precise limit between civilisation that is being composed, and civilisation have already composed" (ibid, p.43).

Bennabi "as an engineer, was trained to utilise various scientific avenues of research, such as observation, hypothesis, development, and analysis" [Bariun, (1993), p.147]. He was aware of the nature of the social phenomenon and its demands, and he stressed that this method should be comprehensive to deal with civilisation in its whole structure, rather than fragmenting the analysis and limiting it to certain parts, and undermining others. The method should be complete and impartial. It should attempt to discover the problem, and study its origin, history, and reason [Bennabi, (1978), p.37].

Bennabi does not rely only on what is given by historians of civilisation whose works are concerned with gathering and interpreting historical events; he stresses the psychosocial analysis provided by both psychology and social science [al-Jafa'iri, (1984), pp.63-64].

These two sciences are very important in Bennabi's approach. He benefits from the tools they provide, and he argues that if civilisation is a social phenomenon, logically it is concerned with humans and society as well.

Hence, he will study the problem of civilisation by using the information provided by history while taking into account the measures of psychoanalysis.

Bennabi holds the view that he should approach the phenomenon of civilisation not as a series of events narrated by history, but as a phenomenon whose analysis guides us to its essence, or perhaps leads us to the pattern of God that governs it. This approach can enable us to study this phenomenon [Bennabi, (1981), p.61] and it demands the integration of the general rules derived from history, sociology, and psychology [Bennabi, (1998), p.89].

Bennabi noted that he would apply the method used in dealing with complicated objects (ibid, Mushkilat al-Thaqāfa, p.40); he tried to integrate the tools into one single system of analysis. Applying this approach, in his view, might assist in understanding the concept of civilisation in its comprehensive sense including the views of the philosophers of history, historians, psychologists, and sociologists.

Bennabi holds the same view about religion as some other historians and philosophers of history, especially Ibn Khalduun and Toynbee. He recognises the significance of religion and insists on it because revelation becomes a crucial element. We cannot focus only on data and facts given by the social and human sciences, but we must necessarily use accurate data provided by religion, as it refers to the divine sources of knowledge.

Bennabi's approach implements the four sciences (history, psychology, sociology, and metaphysics) but it is based on the role of religion, or the religious idea as he calls it, in generating a civilising process in any human society (ibid, Shurūt al-Nahzah, p.71; 
Mīlād Mujtama', p.52). He examines how religion affects humans and society, directing and enabling them to play their roles in history.

The study of civilisation should not only focus on the objects as they are in reality, but also comprehend them in their purpose (ibid, Shurūt al-Nahzah, p.119).

In his discussion of the importance of the four sciences, Bennabi explained his views as follows:

\begin{abstract}
"One could consider the historical phenomenon from various points of view: from the point of view of the individual, it is above all a psychology, that is, a study of man regarded as a psycho-temporal factor of a civilization. However, this civilization is the manifestation of a life and collective thought. From this point of view, history is sociology, that is, the study of the conditions of development of a social group, defined not as much by its ethical or political factors as by the complex of ethical, aesthetic and technical affinities corresponding to the air, or space of a civilization. On the other hand, this social group is not isolated, and its evolution is conditioned by certain connections with the human ensemble. From this point of view, history is metaphysics, since its perspective, extending beyond the domain of historical causality, embraces the phenomena in their finality." (ibid, Qa d़ $\bar{a} y \bar{a}$ Kubrā , p.7)
\end{abstract}

The four elements are integrated into a single system, and the complexity of the phenomenon of civilisation calls for the implementation of different angles and perspectives, a collaborative approach which provides a comprehensive diagnosis and understanding.

It is clear that the study of civilisation and its course in history cannot be satisfactorily tackled through the traditionally known approaches in an isolated manner. It can only be done by applying a collaborative, interdisciplinary approach which will not be comprehended without a discussion on how Bennabi structurally analysed the elements of civilisation in his famous "equation of civilisation".

\title{
4 The elements of civilisation
}

\subsection{The equation of civilisation}

For Bennabi, the formula 'Civilisation $=$ Man + Soil + Time' represents the equation of civilisation which structurally determines its elements or ingredients. It gives us the very basic elements of any civilisational action or product.

Civilisation $=$ Man + Soil + Time, indicates that the problem of civilisation can be analysed into three primary problems: the problem of man, the problem of soil, and the problem of time. Thus, resolving the problem or the question of civilisation could not be done by gathering and stocking its products, but by fundamentally resolving its three problems (ibid, Shurūt al-Nahzah, p.45).

Structurally speaking, three elements produce the product of civilisation: man, matter (soil), and time. While man is the generator and the transformer of the raw material to achieve a certain objective, matter, is the primary source, and time is the necessary period to achieve the objective of producing that product. For example, if we analyse the manufacture of radio, TV, or car from a structural point of view, man, soil (matter), and time are involved.

Bennabi realised that all objects or things which humans produce are the result of three elements: man (Insān), soil (Turāb), and time (Waqt) (ibid), and argues that if we 
analyse all the products of civilisation, the result is the following equation: All products of such a civilisation $=$ all men involved + all sorts of soil (matter) + all managed periods of time. The three elements are always found in any society, and form the fundamentals that enable any society to begin a civilising process (ibid, p.50).

Furthermore, all the ingredients in the mentioned equation are, in a sense, raw materials or original sources that every human society possesses. A positive interaction of these preliminary elements generates a civilising process that can assist society to develop. However, any a problem faces civilisation, cannot be resolved if we are not able to understand the elements that form the equation of civilisation. That is; 'Civilisation $=$ Man + Soil + Time'.

To clarify this, we say that every human product or object of civilisation is the result of these three factors. For instance, the lamp, the radio, the TV, or the cars, as products of a civilisation, represent the direct product of man, soil and time. Therefore, the problem of any civilisation cannot be resolved if people are unable to understand this civilisational equation.

The application of the same analysis to every product of civilisation leads to the discovery that the same elements are involved in the process of their production. They are the result of man as a maker of all social events and a promoter of himself as a social being. Man also promotes the soil. The latter formulates the physical world in which all objects are framed and shaped. The soil constitutes one of the essential components in every object, and these two components, man and soil, interact in a span of time. The more the span of time is organised and planned, the more the interaction produces an oriented civilising process throughout the course of history (ibid, Qaḍāya Kubrā, p.55).

In Bennabi's view, when we plan for a civilisation, it is not our obligation to think of its products and objects. Rather, we should think of three things; man, soil, and time. When we scientifically tackle these three issues; constructing human personality, exploiting the soil and organising time then will civilisation provide the necessary social services and assistance humans need for development (ibid, Ta'ammulāt, p.170).

According to Bennabi's approach, the three elements of man, soil and time are the primary sources for any society at its point of departure to build a new civilisation. "In these three elements the social wealth of any society is located and these are the factors which drive it into history" (ibid, Shurūt al-Nahzah, p.50). When society begins its first steps in history, it does not enjoy many things and ideas, but the civilisational movement that consists of man, soil and time will enable its people to construct what Bennabi calls the world of things and objects.

The three elements are the original values that Allah (SWT; Subhanahu Wa ta'ala; Praise be to Allah) has provided for any people as social wealth. He considers, that "as long as the three core values: man, soil and time (in the time of hardship) in the hands of the people ... the people, no doubt, holds the key of his fate" [Bennabi, (1981), pp.150-151].

\footnotetext{
"the three substantial values; man, soil and time, are the essential input in times of hardship. While these values are in the hands of a people, it can handle the key of development and success.” [Bennabi, (1981), pp.150-151]
}

Bennabi was aware of another element necessary for the dynamic positive or negative interaction of those three elements to formulate civilising or decivilising processes.

Based on historical analysis of world civilisations, in general, and Muslim civilisation, in particular, he realised that all civilisations flourished under the warm 
shadow of the religious idea, whatever that may be. Therefore, he added to his equation of civilisation the element of religion that plays the role of 'catalyst of civilisation' (ibid, pp.45-46).

The following section will analyse the first essential ingredient, man, his importance and status, and the role of religion in the equation of civilisation.

\subsection{Man (Insān), the primary device of civilisation}

According to Bennabi, among the three structural elements of civilisation man is the primary device of society; hence, he is the central force in any civilising process and without him the other two ingredients are of no value. Man is the driving force behind development and progress or backwardness and decline. Bennabi considered it important to mention the dialectic relationship between man and civilisation, "man is the fundamental condition of all civilisations and civilisation constantly fixes the human condition" (ibid, Qa d̦āya Kubrā, p.102; Ta'ammulāt, pp.21-22).

He argues that man is the one who, in the final analysis, determines the social value of the civilisational equation. Although he does not undermine the value of soil and time, they cannot achieve any social or civilisational transformation if we rely on them only (ibid, Fikrat commonwealth Islāmī, pp.52-53).

He assumes also that man has been created in his natural form by Allah (SWT). However, human conditions and social surroundings influence him deeply, and drive him to flourish or decline, which means that man is the outcome of socio-historical factors.

Man is a social being. Historically, people interact with time and space not as natural creatures but as social beings, so their attitude towards life has been shaped by their continuous experience facing the different challenges of life (ibid, Mīlād Mujtama', p.113). Man is that complex being who builds and at the same time is the product of that civilisation.

Bennabi criticised the reformist movement in the Muslim world for its attempt to reform the milieu rather than the human factor itself (ibid, Wijhat al-'Álam al-Islāmī, p.52.), and argues that we must reform man as a primary condition to reforming his milieu. Thus, as his framework for analysing man's status, he uses the verse "indeed, Allah will not change the condition of a people until they change what is in themselves" [The Qura'n, (2004), Chapter 13: Verse 11].

Following is a discussion on Bennabi's concept of integrated man versus disintegrated man, and his idea of orientation which is the mechanism for transforming man into a dynamic device of civilisation.

\subsubsection{The difference between integrated and disintegrated man}

It is obvious that civilisation does not start its civilising process wherever or whenever people meet and assemble in a given place or time. Rather, it starts with a man who is prepared to perform his civilisational responsibilities and who is ready to embark on a civilising process. Bennabi differentiates between two qualities of men: integrated and disintegrated. While civilisation starts its civilising process with the first type of man, it starts its decline with the second.

Bennabi states that "history commences with the integrated man, constantly adapting his effort to his ideal and needs, and accomplishing in society his double mission of actor and witness" [Bennabi, (1988), p.10; (1989), pp.32-33]. In other words, civilisation rises 
with the integrated type of man who is able to transform his characteristics into his ideals in order to undertake his role in his society.

By the same token, "history ends with the disintegrated man, the corpuscle deprived of the centre of gravitation, the individual living in a dissolved society that no longer furnishes his existence with either moral or material base" (ibid, Islam in History and Society, p.10).

The two types of man correspond to two different phases of civilisation. While the integrated man starts the civilising process, the disintegrated man witnesses the phase of decline where he no longer undertakes any civilising action; he has lost all ambition to get involved in any social movement.

To distinguish between integrated and disintegrated man, Bennabi also introduces the raw and the conditioned man.

What he meant by it is that while the first is the product of nature in an unrefined and elementary state, the second is formulated by society. It is the function of society that shapes him according to its specific objectives and orientation.

In the raw state, the human being is acquainted with natural faculties, while in the formulated state with social features. The first one is available in any human being, in his biological structure, and it is represented by his innate ability to use his intelligence, soil, and time, while the second value is represented in the means and experiences the individual finds in his social milieu in order to promote his personality and develop and refine his capacities. Thus, the role of society is but this development and refinement (ibid, Shurūt al-Nahzah, p.145).

Bennabi asserts that

$$
\begin{aligned}
& \text { "... since we have already stressed the fact that human society is not a mere } \\
& \text { aggregate of individuals, it should be more precisely stated that the basic unit of } \\
& \text { a society is not the raw individual; rather it is the conditioned individual." } \\
& \text { [Bennabi, (1998), p.75] }
\end{aligned}
$$

This notion of adaptation or conditioning is clearly expressed by the Prophet (SWS) in the following hadith (Both Imam al-Bukhārī and Imam Muslim report this hadith. al-Bukhārī reported it in his Sahih, Book of Funerals, while Muslim reported it in his Sahih, Book of Fate.): "Every child is born in fitrah (natural disposition) and it is his parents who make him a Jew, a Christian, or a Magian" [Bennabi, (1998), p.76].

Man demands certain transformation from his raw form into the conditioned man who is a type of integrated man. Qualifying man to play his role in history requires such a transformation in his personality and social surroundings. Bennabi stresses the role of the transformed (adapted or conditioned) man in history, and believes that the real process of civilisation should formulate this man. The problem of any civilisation is substantially related to human agency. Thus, any thinking on the problem of man is thinking on the problem of civilisation (ibid, Mushkilat al-Thaqāfah, p.100).

Man is also a vital social force. Bennabi contends that

$$
\begin{aligned}
& \text { "...man is involved in social life as a psycho-temporal factor. He acts not only } \\
& \text { in terms of temporality, of his material needs, but also in terms of his psyche of } \\
& \text { his spirituality, and therein lies the complete reality of man which must be } \\
& \text { taken into account for seizing it in its totality." (ibid, Islam in History and } \\
& \text { Society, p.90) }
\end{aligned}
$$

This is the complete picture Bennabi draws for the man of civilisation (the integrated man). 
When Bennabi dealt with the problem of civilisation in the Muslim world, he directed our attention to this kind of man. Our crucial need, he explains, is in the realm of persons more than the realm of things... our primary need is the new man... the civilised man... the man who comes back again to a history which our civilisation has left for a long time (ibid, Ta'ammulāt, pp.190-191).

How to promote such an integrated man? Through the process of transforming him from his raw state into the conditioned state which enables him to be integrated and ready to play his role in the civilising process.

\subsection{Religion and its position in the equation of civilisation}

Bennabi's equation of civilisation is based on three fundamental elements; man, soil, and time, to which he added another element, religion, just as important but not a structural factor in the equation. Religion is a catalyst, motivator, and provider of the milieu in which the three elements enter into dynamic interaction to form civilisation.

\subsubsection{The importance of religion as a catalyst}

For Bennabi, the 'catalyst of civilisation' is that element that has the power to blend and synthesise the other three elements into dynamic interaction in order to formulate a civilisation. As proved by the historical analysis, it is found that this catalyst is really 'a religious idea' which always accompanied the construction of civilisation through history (ibid, pp.45-46).

Belief in a religion accompanies the process of constructing civilisation in history (ibid, pp.45-46).

For Bennabi, it is the stimulus that facilitates and activates that interaction, and the rationale behind that claim refers us to history and archaeology.

History is the laboratory that confirms this experiment of synthesising man, soil, and time to formulate history in light of religious ideas. Bennabi argues that if we study the history of civilisations

$$
\begin{aligned}
& \text { "...we will find clearly, that all civilizations have their roots in religious } \\
& \text { sentiments. For history will tell us that the Buddhist civilization has its roots in } \\
& \text { Buddhism, the Muslim civilization in Islam and the Western civilization in } \\
& \text { Christianity." (ibid, Ta'ammulatt, p.198) }
\end{aligned}
$$

Religion is a pivotal coefficient in the equation of civilisation, without which the three values (elements: man, soil and time) cannot be organised and directed towards their civilising process.

Those three elements do not work in a separate or isolated form, but within a harmonious synthesis by which civilised society possesses its will and power. Subsequently, the problem of this harmonious synthesis becomes crucial (ibid, Qad $\bar{a} y \bar{a}$ Kubrā, p.58).

The importance of religion in Bennabi's approach is not only related to its essence and divine source, but essentially to its social role as a catalyst of human energies and capacities. As a social thinker, Bennabi was looking for the conditions needed to bring about the renaissance of a new civilisation in the Muslim world. Thus, he was looking for ways to reactivate those primary elements of civilisation, and to discover how to integrate them. Religion makes a spiritual relationship network that links the souls of society with 
the faith in God, on the one hand, and brings together the members of society in a horizontal network of relationships, on the other. In other words, Bennabi aimed to provide a paradigm which extends beyond earthly life [Talbi, (1991), p.13].

As a Muslim social thinker, Bennabi emphasises the role of religion in resolving the problems of civilisation. He was influenced by the example of the first generation of Islam founded by the Prophet Muhammad (SWS) and his companions, and their practical understanding of Islam. He insists that there is need to show man how to live in relation to Allah, and to believe in Him. He emphasises that this is the way to make the soul surpass its limitations to achieve a high level of efficiency and brightness [Bennabi, (1988), p.54].

Returning to his theoretical concept of the role of religion, Bennabi asserts that "The social role of religion is essentially that of a catalyst, favouring the transformation of values that pass from a natural to a psycho-temporal state, corresponding to a certain stage of civilisation" (ibid, p.11). First, it turns the biological man into a sociological entity. Second, it turns time-simple chronological duration evaluated in "hours that pass" - into sociological time, evaluated in hours of labour. Third, it turns soil-yielding unilaterally and unconditionally the nourishment for man according to a simple process of consumption - into a technically equipped and conditioned ground for catering for the multiple needs of social life according to the conditions of a process of production. Religion is then the catalyst of social values (ibid).

In other words, religion makes three changes: it unites the network of social relations, it motivates common activity motivates and enables common activity, and it changes the psychological attitudes of individuals in society. Talbi sees that in Bennabi's notion, religion enables society to undertake common activity, and changes the behaviour of the individual by directing his/her vital powers towards achieving a specific purpose [Talbi, (1991), p.13]. This psychological change (of individuals and society) is a prerequisite to any social change necessary to bring about the historical and organic construct made up of the three elements of society: man, soil and time.

All civilisations, without exception in history, have flourished in the shadow of religious ideas. However, in Bennabi's approach, religion cannot begin its civilising function as a catalyst unless it embarks upon a civilising process that assembles man, soil, and time in one project.

Bennabi considers that history and archaeology can assist in proving the importance of religion in the civilising process, and help to give a raison d'être to his claim.

He states:

"As far back as we look into the past history of man, either into the most beautiful periods of his civilization or into the most rudimentary stages of his social evolution, we always find there a trace of religious thought. Archaeology has always revealed, among the vestiges, which it brings to light, the remnants of monuments that were consecrated to some cult by the ancients. For the simple dolmen to the most imposing temple, architecture has evolved on a par with religious thought, which also included the laws and even the science of man. Besides, civilizations were born in the shadow of temples, such as that of Solomon, or that of the $\mathrm{Ka}$ ' $b a$. Thus, it was from these places that civilization radiated out to illuminate the world to brighten its universities and laboratories and to enlighten in particular, the political debates in parliaments. The laws of modern nations are essentially canonical. As for their civil laws, there is not least of religious essence in France, particularly where it was borrowed from Muslim law. Customs and habits of peoples are modelled by a metaphysical preoccupation, which sends even the smallest Negro village around a small hut 
especially and carefully built for the more or less primitive spiritual life of the people." (ibid, The Qur'anic Phenomenon, p.69)

Every civilisation started from a religious drive that pushed society to begin the civilising process. Religion is naturally inscribed in the origin of all human transformations (ibid, Islam in History and Society, p.89). In fact, he argues that these contemporary civilisations (Hindu, Buddhist, Christian and Muslim...) formulated the original dynamic synthesis of man, soil, and time in the cradle of a religious idea (ibid, Qaḍ $\bar{a} y \bar{a}$ Kubrāa, p.60).

Civilisation does not begin without the emergence of a religious idea in its broadest sense. Therefore, in any civilisation we have to search for the religious foundations that made it rise. It is not too much to claim that we could find in Buddhism the seeds of Buddhist civilisation and in Brahma the seeds of Brahman civilisation. Civilisation cannot appear in a given society except in the form of revelation (in its broadest sense) which is revealed in order to formulate legislation and a method for people. However, the religious idea does not play its social role in the formation and development of social reality, only if it is sticking to its metaphysical value. That is; if it is only reflecting our view beyond the earthly matters (ibid, Shurūt al-Nahzah, p.14).

\subsubsection{Bennabi's meaning of religion}

Generally, by religion Bennabi does not mean Islam per se, but includes all religions, quasi-religions and ideologies. Religion, for Bennabi, connotes any kind of relation between a human being and a power of divine or social nature. Any idea or ideology that formulates a sort of commitment and relation among the members of a society, and that directs peoples. In other words, Bennabi includes in the broad meaning of religion any long-term social project; for constructing a society where the first generation takes the first step, and other generations will continue the project (ibid, p.51).

However, for Bennabi, there is a difference between religions in their originality and method.

Relying on the Qur'an and the various sciences mentioned previously, Bennabi sees religion as part of the cosmic order. He says: "in the light of Qur'an, religion appears as a cosmic phenomenon, regulating man's thought and civilisation as gravity regulates matter and conditions its evolution. It appears also as part of the universal order, as both the original law of the soul and the law of the physical bodies" (ibid, p.184). It is the source of the perspectives which civilisation adopts.

Religion is not a mere spiritual and mental activity of the human psyche. Rather, it is both a fundamental disposition of the human species and a part of the cosmic order deeply rooted in the structure of the universe. This means that religion cannot be reduced to a mere moral category acquired by the human species over history, or relative to the primitive stages of human socio-cultural development.

Mesawi observed that Bennabi is not the first to mention this issue, for his ideas merely support the same position held by different philosophers, moralists, theologians and social scientists. The religious phenomenon is inherent in human nature (ibid, p.15), therefore 'Homo Religious' is a quality inherent in the nature of human beings [Bennabi, (1988), p.155].

Bennabi, in a more theoretical vein, claims that every piece of work or action in society is formulated from three categories derived from the elements of civilisation. In 
any work, activity, or action, we find man as worker, the instruments used to perform such an activity or action, and the idea behind that action

\section{Conclusions}

To conclude with, it is a clear from the present paper that Bennabi was concerned about providing a conceptual framework to resolve the present situation of Muslim society. This led him to formulate his own concept of civilisation, which is in its essence multidimensional, and needs an interdisciplinary approach.

To do so, Bennabi used the analytical method to provide us with the structural elements of civilisation, man, soil, and time, and introduced his concept of religious ideas as the catalyst of civilisation. Moreover, Bennabi's concept of man as the primary device of civilisation, his idea of orientation, and the concept of the integrated versus the disintegrated man are elaborated.

\section{References}

al-Jafa'iri, M.A. (1984) Mushkilat al-Ĥđāarah 'Inda Malek Bennabi, al-Dar al-Arabiya Li al-Kitab, Tunis.

Al-Khatīb, S. (1986) Usus Falsafat al-Hadāara Fī al-Islām (The Basics of the Concept of Civilization in Islam), Maktabat al-Zahrā', Cairo.

Al-Mīlād, Z.A. (1992) Malek Bennabi Wa Mushkilāt al-Haḍāra (Malek Bennabi and the Problems of Civilization), 1st ed., Dār al-Ṣafwa, Beirut.

Al-Saḥmarān̄̄, A. (1986) Malek Bennabi Mufakkiran Ișlāḥiyyan (Malek Bennabi: A Reformer Thinker), 2nd ed., Dār al-Nafā'is, Beirut.

Arif, N.M. (1994) Hadārah, Thaqāfah, Madaniyyah (Civilization, Culture and Urbanization), p.252, International Institute of Islamic Thought, Herndon.

Bariun, F. (1993) Malek Bennabi: His Life and Theory of Civilization, Petaling Jaya: Budaya Ilmu Sdn. Bhd., p.ix.

Bennabi, M. (1978) Bayna al-Rashād Wa al-Tayh (Between the Maturity and the Wilderness), Dār al-Fikr, Damascus.

Bennabi, M. (1981) Shurūt al-Nahzah (The Conditions of the Renaissance), Dār al-Fikr, Damascus, p.19.

Bennabi, M. (1986) Ta'ammulāt (Contemplations), Dār al-Fikr, Damascus, p.116.

Bennabi, M. (1988) Islam in History and Society, Trans by: Asma Rashid, Islamic Research Institute, Islamabad.

Bennabi, M. (1989) Wijhat al-'Ālam al-Islāmī (The Course of Muslim World), Dār al-Fikr, Damascus.

Bennabi, M. (1994) The Problem of Ideas in The Muslim World, Trans by: Mohamed T. Mesawi, Petaling Jaya, Budaya Ilmu Sdn. Bhd, p.26.

Bennabi, M. (1998) On the Origins of Human Society, Trans. by Mohamed T. Mesawi, The Open Press, Kuala Lumpur, pp.9-10; from the introduction by the translator.

Gassum, Adb al-Razzaq (1994) Ishkaliyat al-Ĥđađarah Fì Fikr Malek Bennabi (Te Problem of Civilization in Malek Bennabi's Thought), Al-Muwāfaqāt, Vol. 3, pp.290-298.

Hassan, M.K. (1991) 'Reflections on some of the ideas and thoughts of Malek Bennabi', Paper presented at the International Seminar on Malek Bennabi, University Malaya, Malaysia, September.

Huntington, S.P. (1993) 'The clash of civilizations', Foreign Affairs, Vol. 72, No. 3, pp.22-49. 
Huntington, S.P. (1996) The Clash of Civilizations and the Remaking of World Order, Simon \& Schuster, New York, p.40.

Ibrahim, A. (1991) 'Keynote address', The International Seminar on Malek Bennabi, Kuala Lumpur, Institute of Advanced Studies, University of Malaya, September.

Jad'an, F. (1988) Usus al-TaQaḍdum 'Inda Mufakkirī al-Islām fi al-'Ālam al-'Arabì al-Hadìth (Foundations of Progress according to the Muslim Thinkers in the Modern Arab World), 3rd ed., Dār al-Shurūq, Amman.

Mesawi, M.T. (1991) 'Malek Bennabi’s contribution to the Islamic social theory', Paper presented at the International Seminar on Malek Bennabi, University Malaya, Malaysia.

Mesawi, M.T. (1998) A Muslim Theory of Human Society. An Investigation into the Sociological Thought of Malek Bennabi, Thinker's Library Sdn. Bhd., Batu Caves.

Rachid, A. (1978) 'Iqbal and Malek Bennabi', Hamdard Islamicus, Vol. 1, No. 2, 1978, p.12.

Sanderson, S.K. (1995) 'Civilizational approaches to world-historical change', in Sanderson, S.K. (Ed.): Civilizations and World Systems, p.15, Altamira, Walnut Creek.

Talbi, A. (1991) 'The implication of Malek Bennabi's view on contemporary Muslim society', Paper presented at the International Seminar on Malek Bennabi, University Malaya, Malaysia, September, p.1.

The Qura'n (English Meanings) (2004) English Revised and Edited by Shaheen International, Al-Muntada Al-Islami, London.

Toynbee, J.A. (1974) A Study of History, Abridgement by: D.C. Somervell, Oxford University Press, Oxford.

Ubādah, 'A.a-L. (1984) Șafaḥāt Mushriqa Min Fikr Malek Bennabi (Some Shiny Aspects of Malek Bennabi's Thought), Dār al-Shihāb, Batna.

Ukāshah, S. (1986) al-Sirā̄' al-Had̄ārī F̄̄ al-'Ālam al-Islāmì (The Civilizational Conflict in the Muslim World), 1st ed., Dār al Fikr, Damascus. 